\title{
PENGEMBANGAN VIDEO PEMBELAJARAN MUATAN PELAJARAN IPA UNTUK SISWA KELAS IV SD
}

\author{
S.H. Wijaya ${ }^{1}$, I.M. Tegeh ${ }^{2}$, I.K.Suartama ${ }^{3}$ \\ ${ }^{123}$ Jurusan IImu Pendidikan, Psikologi dan Bimbingan \\ Universitas Pendidikan Ganesha \\ Singaraja, Indonesia \\ e-mail: sofyanhadiwijaya@undiksha.ac.id ${ }^{1}$, im-tegeh@undiksha.ac.id ${ }^{2}$, \\ ik-suartama@undiksha.ac.id ${ }^{3}$
}

\begin{abstract}
Abstrak
Penelitian ini bertujuan untuk mendeskripsikan kualitas hasil validasi media video pembelajaran yang dikembangkan berdasarkan penilaian ahli isi, desain, media, uji perorangan dan kelompok kecil. Model pengembangan yang digunakan yaitu model ADDIE (analyze, design, development, implementation, evaluation). Data dalam penelitian ini dikumpulkan dengan metode wawancara dan tes objektif. Hasil penelitiannya sebagai berikut (1) Rancang bangun media video pembelajaran dibuat dalam naskah video. Naskah ini diwujudkan menjadi media video pembelajaran melalui tahapan pengembangan ADDIE. (2) Hasil validitas media video pembelajaran berdasarkan penilaian ahli isi yaitu $88 \% \%$ dengan kualifikasi baik, ahli desain pembelajaran, diperoleh persentase $92 \%$ dengan kualifikasi sangat baik, penilaian ahli media pembelajaran, diperoleh persentase $85 \%$ dengan kualifikasi baik. Persentase yang diperoleh dari hasil uji perorangan yaitu $97,14 \%$ dengan kualifikasi sangat baik. Hasil uji kelompok kecil diperoleh $99.04 \%$ dengan kualifikasi sangat baik. Dengan demikian media video pembelajaran yang dikembangkan efektif meningkatkan hasil belajar siswa. Saran dari penelitian ini adalah agar guru memanfaatkan media video pembelajaran yang dikembangkan dalam proses pembelajaran.
\end{abstract}

Kata kunci: Hasil Belajar; Media Video Pembelajaran; Pengembangan

\begin{abstract}
This study aims to describe the quality of learning video media validation results developed based on expert assessment of content, design, media, individual and small group tests. The development model used is the ADDIE model (analyze, design, development, implementation, evaluation). The data in this study were collected by interview methods and objective tests. The results of the research are as follows (1) The design of the learning video media is made in a video script. This manuscript is transformed into a learning video media through the ADDIE development stage. (2) The results of the validity of the learning video media based on the assessment of content experts, namely $88 \%$ with good qualifications, learning design experts, obtained a percentage of $92 \%$ with very good qualifications, the assessment of learning media experts, obtained a percentage of $85 \%$ with good qualifications. The percentage obtained from the individual test results is $97,14 \%$ with very good qualifications. Small group test results obtained $99,04 \%$ with very good qualifications. Thus, the learning video media that has been developed is effective in improving student learning outcomes. Suggestions from this study are for teachers to use instructional video media developed in the learning process.
\end{abstract}

Keywords : Learning Outcomes; Learning Video Media; Development

\section{PENDAHULUAN}

Pertama kalinya krisis kesehatan terjadi di belahan dunia terutama di Indonesia diakibatkan oleh munculnya Virus Covid-19 memaksa pemerintah menghimbau seluruh masyarakatnya untuk mengkarantina mandiri. Hal ini memaksa negara-negara untuk menutup kegiatan-kegiatan yang 
melibatkan banyak orang seperti Perkantoran,Pasar,Daerah Parawisata tak terkecuali Lembaga Pendidikan (sekolah dasar, sekolah menengah dan perguruan tinggi). Kemendikbud melalui surat edaran nomor 4 tahun 2020 tentang pelaksanaan kebijakan pendidikan dalam masa darurat Penyebaran Covid-19 menerangkan untuk menangapi penyebaran covid-19 yang semakin meningkat maka dihimbau untuk melaksanakan proses pembelajaran dari rumah melalui model pembelajaran daring (Kemendikbud,2020).

Hasil survei yang dilakukan Kementrian Pendidikan dan Kebudayaan pada April 2020 menunjukkan 97,6 persen sekolah telah melaksanakan kegiatan belajar dari rumah, menyisakan 2,4 persen sekolah yang masih tetap menjalankan kegiatan belajar-mengajar di instansi pendidikan dikarenakan belum adanya jaringan internet atau perangkat pendukung pelaksanaan belajar dari rumah kondisi ini biasa terjadi di daerah dengan kualitas jaringan internet yang buruk meski berada di pinggiran kota (CNN Indonesia, 2020).

Perubahan strategi penyampaian pembelajaran ini memaksa guru dapat beradaptasi dalam mengajar, guru yang sebelumnya terbiasa mengajar dengan model pembelajaran yang bersifat tatap muka, kini harus bertemu melalui sosial media atau platffrom yang mendukung pembelajaran daring. Munir (2009) menjelaskan bahwa pembelajaran daring akan efektif jika melibatkan interaksi antara pembelajar dengan pengajar, pembelajar dengan pembelajar, pembelajar dengan media pembelajaran (termasuk fasilitas). Pola interaksi pembelajaran berlangsung secara aktif dan interaktif. Media pembelajaran atau trade-off teknologi yang digunakan dalam interaksi face-to-face langsung antara pembelajar dan pengajar seperti halnya dalam pembelajaran konvensional dapat dicapai atau bahkan mendekati. dari pendapat diatas menunjukan pengunaan media pembelajaran dimasa pandemi covid-19 sangat penting, pemilihan media yang ingin digunakan pun beragam seperti media Audio, Gambar, Video dan media lainya.

Media pembelajaran erat kaitanya dengan definisi Teknologi Pendidikan, sesuai dengan definisi yang dikeluarkan Association for Educational Communication and Technology (AECT) dalam (Putri et al., 2019) menyatakan "Teknologi Pendidikan merupakan kajian dan praktek etika tentang memfasilitasi belajar dan meningkatkan kinerja dengan menciptakan, menggunakan, dan mengelola proses dan sumber teknologi yang tepat". Berdasarkan definisi diatas dapat ditarik kesimpulan bahwa sebagai Teknolog pembelajaran memiliki peran menciptakan dan memfasilitasi pembelajaran siswa melalui pengunaan sumber belajar diantaranya media pembelajaran. Dengan demikian media memiliki peran penting dalam memfasilitasi siswa mencapai hasil belajar yang maksimal.

Berdasarkan hasil observasi dan wawancara yang dilakukan pada tanggal 27 Februari 2021 pukul 10:00 Wita, dengan lbu Khrisna sebagai wali kelas IV B SD Negeri 4 Kampung Baru, diperoleh hasil belajar siswa pada muatan pelajaran IPA yang rendah, hal tersebut dibuktikan dengan data hasil belajar yang didapatkan dari wali kelas. Dari 24 siswa, ditemukan 16 siswa yang tidak lulus KKM (Kriteria Ketuntasan Minimal) dan 8 siswa yang memperoleh hasil tuntas. Hal tersebut di sebabkan oleh berbagai faktor diantaranya, guru yang masih cenderung terpaku pada satu bahan ajar yaitu buku atau modul yang sudah disediakan oleh pihak sekolah, siswa memiliki minat belajar yang rendah pada saat proses pembelajaran mandiri dan guru kurang kreatif dan inovatif dalam memanfaatkan sarana dan prasarana yang ada disekolah.

Kunandar dalam (Imansari \& Sunaryantiningsih, 2017) berpendapat bahwa hasil belajar merupakan kompetensi yang dikuasasi setelah siswa mengikuti proses pembelajaran. Dari pendapat diatas dapat di petik pemahaman bahwa hasil 
belajar merupakan komponen penting dalam suatu proses pembelajaran disekolah. Hasil belajar digunakan sebagai tolak ukur bagi siswa dalam muatan pelajaran dimana semakin tinggi nilai siswa tersebut itu berarti semakin tinggi kemampuan dan pemahaman siswa terhadap muatan pelajaran tersebut. Pendapat serupa juga disampaikan Lestari (2015) bahwa berhasil atau tidaknya proses pembelajaran dapat diukur melalui hasil belajar yang diperoleh, jika hasil belajar siswa cenderung baik berarti proses pembelajaran sudah berjalan dengan baik. Begitu pun sebaliknya jika hasil belajar cenderung buruk maka proses pembelajaranya mengalami kendala.

Hamalik dalam (Arsyad, 2003) mengemukakan bahwa pemakaian media pembelajaran dalam proses belajar mengajar dapat membangkitkan keinginan dan minat yang baru, membangkitkan motivasi dan rangsangan kegiatan belajar bahkan membawa pengaruh psikologis yang baru terhadap siswa. Pendapat tersebut juga didukung oleh Tafonao (2018) menyatakan dengan media, siswa akan lebih termotivasi untuk belajar serta mendorong siswa menulis, berbicara dan berimajinasi sehingga proses pembelajaran lebih efektif dan efesien serta terjalin hubungan baik antara guru dengan peserta didik. Adapun menurut Bavaharji et al., (2014) bahwa pemanfaatan video dapat meningkatkan kemampuan bahasa siswa sehingga mempermudah siswa dalam memahami materi yang disampaikan. Penggunaan media dalam proses pembelajaran sangat penting dalam meningkatkan minat/motivasi belajar yang nantinya berpengaruh terhadap hasil belajar siswa, oleh sebab itu diperlukannya mengembangkan media pembelajaran yang mampu meningkatkan minat dan hasil belajar siswa.

Dilihat dari fungsi media video sebagai media pembelajaran Arsyad (2003) berpendapat ada empat fungsi diantaranya: fungsi atensi,fungsi afektif, fungsi kongnitif, dan fungsi komfensantoris. Dilihat dari fungsi atensi, media video dapat menarik perhatian siswa dan mengarahkan konsentrasi siswa pada materi yang dijelaskan. Fungsi afektif dimana media video mampu mempengaruhi emosi dan sikap siswa. fungsi kongnitif dapat mempercepat tercapainya tujuan pembelajaran dalam memahami dan mengingat materi yang terdapat dalam media video. Sedangkan dilihat dari fungsi komfensantoris, media video memberikan konteks kepada siswa yang memiliki kemampuan lemah dalam mengorganisasikan dan mengingat materi yang diperoleh. Dengan demikian media video pembelajaran dapat membantu siswa dalam belajar baik itu siswa yang memiliki daya ingat lemah maupun sedang dan dapat meningkatkan minat belajar siswa guna mecapai tujuan pembelajaran.

Berdasarkan permasalahan diatas, dipandang perlu mengembangkan media video pembelajaran dalam proses pembelajaran sehingga dapat meningkatkan minat dan hasil belajar siswa dan mudah digunakan guru dalam menjelaskan materi pembelajaran guna tercapainya tujuan pembelajaran. Untuk itu perlu dikembangkanya penelitian dengan judul "pengembangan media video pembelajaran pada muatan pelajaran IPA untuk siswa kelas IV B semester ganjil tahun pelajaran 2021 /2022 di SD Negeri 4 Kampung Baru".

\section{METODE}

digunakan Model penelitian yang pengembangan. Pengembangan yang digunakan dalam pengembangan media video pembelajaran pada muatan pelajaran IImu Pengetahuan Alam Kelas IV adalah model pengembangan produk yakni ADDIE (analyze, design, development, implemetation, evaluation).

Pada tahap analisis kebutuhan (analyze) dilakukan kegiatan observasi dan wawancara untuk mengetahui kebutuhan pembelajaran, lingkungan belajar dan materi 
pelajaran. Tahap desain (design) pada tahap ini dilakukan memindahkan informasi yang diperoleh pada tahap sebelumnya ke dalam bentuk dokumen berupa Naskah Video dan Storyboard. Tahap pengembangan (development) dilakukan kegiatan produksi media video pembelajaran sesuai dengan hasil tahap sebelumnya, pada tahap ini juga dilakukan penilaian oleh para ahli. Tahap implementasi (implemetation) yang dilakukan pada tahap ini yakni menerapkan media video pembelajaran kepada siswa untuk di uji perorangan dan uji kelompok kecil. Dan tahap terakhir yakni evaluasi (evaluation) yang meliputi kegiatan penilaian media berdasarkan evaluasi formatif yang dilakukan untuk mengukur atau menilai produk yang sudah dikembangkan.

Penelitian pengembangan ini dilakukan di SD N 4 Kampung Baru khususnya pada siswa kelas IV yang berjumlah 24 orang. Pengumpulan data dalam penelitian ini menggunakan metode observasi, metode wawancara, metode pencatatan dokumen dan metode kuesioner. Observasi dilakukan untuk mengetahui berbagai hal seperti sarana dan prasarana yang ada di sekolah, proses belajar mengajar, kendala guru dan siswa dalam proses pembelajaran. Wawancara dilakukan untuk mengetahui seberapa jauh penggunaan media dalam proses pembelajaran dan kendala yang dialami guru selama proses mengajar. Adapun beberapa dokumen yang didapat dalam penelitian ini antara lain, hasil belajar siswa (nilai ulangan siswa) kelas IV SD N 4 Kampung Baru dan Rencana Pelaksanaan Pembelajaran (RPP) IPA terkait dengan materi Sumber Energi. Terakhir adalah metode kuesioner untuk mengetahui validitas produk yang dikembangkan dari ahi isi/materi pembelajaran, ahli desain pembelajaran, ahli media pembelajaran, uji perorangan dan uji kelompok kecil. Adapun kisi-kisi instrumen pada penelitian ini adalah sebagai berikut.

Tabel 1. Kisi-Kisi Instrumen Ahli Isi Pembelajaran

\begin{tabular}{lll}
\hline No & \multicolumn{1}{c}{ Aspek } & \multicolumn{1}{c}{ Indikator } \\
\hline & & 1. Ketepatan penyampaian tujuan pembelajara \\
1. & & 2. Ketepatan konsep/materi yang disampaikan \\
& Presenter & 3. Kejelasan Bahasa yang digunakan \\
& & 1. Kesesuaian Materi dengan Tujuan Pembelajaran \\
& 2. Ketepatan Materi \\
2. & 3. Kelengkapan Materi \\
& & 4. Kedalaman Materi \\
& 5. Sistematika Materi \\
& 6. Kemenarikan Materi \\
& 7. Kejelasan Contoh yang disertakan \\
\hline
\end{tabular}

Sumber :(Sungkono, 2012)

Tabel 2. Kisi-Kisi Instrument Uji Coba Ahli Desain Pembelajaran

\begin{tabular}{|c|c|c|}
\hline No & Aspek & Indikator \\
\hline \multirow{3}{*}{1} & \multirow{3}{*}{$\begin{array}{l}\text { Teknik/Metode } \\
\text { Penyampaian } \\
\text { Materi pada } \\
\text { Video }\end{array}$} & 1. Ketersediaan Petunjuk Pengunaan Video \\
\hline & & 2. Ketepatan Strategi Penyampaian Materi pada Video \\
\hline & & $\begin{array}{l}\text { 3. Kesesuaian Metode Pembelajaran yang Melandasi } \\
\text { Pengembangan Video }\end{array}$ \\
\hline
\end{tabular}

Sumber : (Sudarma et al., 2015) 
Tabel 3. Kisi-kisi Instrumen Ahli Media Pembelajaran

\begin{tabular}{|c|c|c|}
\hline No & Aspek & Indikator \\
\hline 1 & $\begin{array}{l}\text { Kelengkapan } \\
\text { Komponen } \\
\text { Video } \\
\text { Pembelajaran }\end{array}$ & $\begin{array}{l}\text { 1. Aspek Konten } \\
\text { 2. Pengunaan Warna } \\
\text { 3. Backsound/Musik Pengiring } \\
\text { 4. Pengunaan Ilustrasi/Gambar pendukung } \\
\text { 5. Pengunaan Presenter/pembawa Materi } \\
\text { 6. Pengunaan Bahasa }\end{array}$ \\
\hline 2 & $\begin{array}{l}\text { Ketepatan } \\
\text { Durasi }\end{array}$ & 1. Kesesuaian Durasi \\
\hline 3 & $\begin{array}{l}\text { Pengunaan } \\
\text { Resolusi Tinggi }\end{array}$ & 1.Kualitas Kejelasan Video \\
\hline
\end{tabular}

Sumber : (Sudatha et al., 2015)

Tabel 4. Kisi-kisi Instrument Uji Coba Perorangan dan Kelompok Kecil

\begin{tabular}{llll}
\hline No & \multicolumn{1}{c}{ Aspek } & \multicolumn{1}{c}{ Indikator } \\
\hline & & Kelengkapan & 1. Pengunaan Warna \\
1 & Komponen & 2. Backsound/Musik \\
& Pembelajaran & 3. Pengunaan Ilustrasi/gambar \\
& & 4. Kemenarikan Presenter/pembawa Materi \\
\hline 2 & Aspek Penyajian Materi & 5. Pengunaan Bahasa \\
\hline 3 & Ketepatan Durasi & 1. & 1. Ketode Penyampaian Materi \\
\hline
\end{tabular}

Sumber :(Sudarma et al., 2015)

Pada penelitian pengembangan ini hanya mengunakan 2 metode analisis data, yakni metode analisis deskriptif kualitatif dan metode analisis deskriptif kuantitatif. Teknik analisis deskriptif kuantitatif ini digunakan untuk mengolah data yang bersifat kualitatif dari hasil review ahli isi bidang studi atau mata pelajaran, ahli desain pembelajaran, ahli media video pembelajaran, uji perorangan dan kelompok kecil. Sedangkan Teknik analisis deskriptif kuantitatif digunakan untuk mengolah data yang diperoleh dari angket dalam bentuk deskriptif persentase dengan pengunaan konversi tingkat pencapaian skala 5 dengan acuan tabel konversi tingkat pencapaian skala 5 yang diadaptasi dari (Tegeh \& Jampel, 2017:223).

Tabel 5. Konvensi Tingkat Pencapaian dengan Skala 5

\begin{tabular}{ccc}
\hline Tingkat Pencapaian $(\%)$ & Kualifikasi & Keterangan \\
\hline $90-100$ & Sangat baik & Tidak perlu direvisi \\
$80-89$ & Baik & Sedikit direvisi \\
$65-79$ & Cukup & Direvisi secukupnya \\
$55-64$ & Kurang & Banyak hal yang direvisi \\
$1-54$ & Sangat Kurang & Diulangi membuat produk \\
\hline
\end{tabular}

\section{HASIL DAN PEMBAHASAN}

Pengembangan media video pembelajaran menggunakan model pengembangan ADDIE yang terdiri dari 5 tahap pengembangan (1) tahap analisis kebutuhan (analyze) dilakukan untuk mengetahui kebutuhan yang diperlukan guru maupun siswa dengan menggunakan 
metode observasi dan wawancara yang kemudian dievaluasi terhadap hasil dari tahap analisis kebutuhan tersebut. Tahap pertama yaitu analisis kebutuhan yang dilakukan di SD N 4 kampung Baru diperoleh informasi bahwa hasil belajar dan motivasi belajar ilmu pengetahuan alam (IPA) siswa masih rendah, hal tersebut dipengaruhi oleh kurangnya penggunaan media yang inovatif dalam proses pembelajaran lebih-lebih siswa belajar secara mandiri di rumah. Selain itu dalam proses belajar IPA siswa cenderung kurang tertarik karena proses pembelajaran yang kurang menarik perhatian siswa. Hal tersebut berdampak terhadap hasil belajar siswa yang kurang baik, sehingga siswa membutuhkan media yang dapat membantu dan menarik perhatiannya dalam proses belajar khususnya pada pembelajaran IPA.

(2) Tahap desain (design), merupakan tahap dalam mendesain produk media video pembelajaran adapun kegiatan yang dilakukan pada tahap ini yaitu membuat rencana pelaksanaan pembelajaran, indikator pembelajaran, storyboard, naskah video, dan instrumen penilaian media, kemudian dilakukan tahap evaluasi berdasarkan hasil dari tahap desain. (3) Tahap pengembangan (development) dilakukan pembuatan media video pembelajaran sesuai dengan pada tahap sebelumnya serta mengembangkan instrumen-instrumen penilaian yang akan di ajukan pada tahap selanjutnya. (4) Tahap implementasi (implemetation) setelah produk yang dikembangkan pada tahap sebelumnya sudah rampung maka tahap selanjutnya yakni melakukan uji validitas terkait media video pembelajaran berdasarkan uji ahli isi/materi, uji desain pembelajaran, uji media pembelajaran, uji coba perorangan dan uji coba kelompok kecil. (5) Evaluasi (evaluation) tahap evaluasi merupakan tahap terakhir dimana pada tahap ini dilakukan evaluasi formatif yang dilakukan untuk menilai produk yang sudah dikembangkan.

Uji validitas media video pembelajaran "Selalu Berhemat Energi" dilakukan untuk menguji tingkah validitas dengan kata lain apakah media video yang dikembangkan sudah teruji tingkat kelayakan nya. Uji validitas dilakukan dengan menggunakan kuesioner penilaian yang sudah disiapkan sebelumnya. Adapun hasil validitas pengembangan media video pembelajaran menurut uji ahli isi/materi pembelajaran, desain pembelajaran, media pembelajaran, uji kelompok perorangan dan uji kelompok kecil, secara lebih rinci dapat dilihat pada tabel 6 berikut.

Tabel 6. Hasil Review Hasil Validitas Produk

\begin{tabular}{llcc}
\hline No & Subjek & Hasil Validitas & Keterangan \\
\hline 1 & Uji Ahli Isi/Materi Pembelajaran & $88 \%$ & Baik \\
2 & Uji Ahli Desain Pembelajaran & $92 \%$ & Sangat Baik \\
3 & Uji Ahli Media Pembelajaran & $85 \%$ & Baik \\
4 & Uji Coba Perorangan & $97,14 \%$ & Sangat Baik \\
5 & Uji Coba Kelompok Kecil & $99,04 \%$ & Sangat Baik \\
\hline
\end{tabular}

Berdasarkan uji validitas yang sudah dilakukan dengan menggunakan kuesioner sebagai instrumen penilaian, diperoleh hasi sebagai berikut. Uji ahli isi/materi dengan menunjuk dosen ahli pembelajaran ilmu pengetahuan alam sebagai penilaian mendapat hasil $88 \%$ dengan kualifikasi baik, selanjutnya uji ahli desain pembelajaran mendapatkan hasil 92\% dengan kualifikasi sangat baik dan uji ahli media pembelajaran mendapat hasil $85 \%$ dengan kualifikasi baik setelah dilakukan uji ahli, selanjutnya dilakukan uji coba produk dengan menunjuk siswa sebagai penilai. Dalam uji coba ini dilakukan 2 tahap yakni tahap pertama uji coba perorangan dengan melibatkan 3 
orang siswa SD N 4 Kampung Baru di dapat hasil $97,14 \%$ dengan kualifikasi sangat baik dan yang kedua tahap uji coba kelompok kecil dengan melibatkan 9 siswa SD $\mathrm{N} 4$ kampung Baru didapatkan hasil 99,04\% dengan kualifikasi sangat baik. Adapun beberapa tampilan produk yang telah dikembangkan akan disajikan pada gambar dibawah ini.

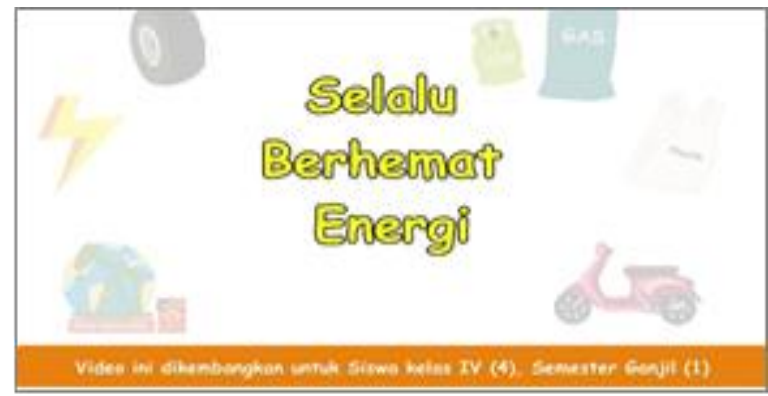

Gambar 1. Tampilan Awal Media Video Pembelajaran

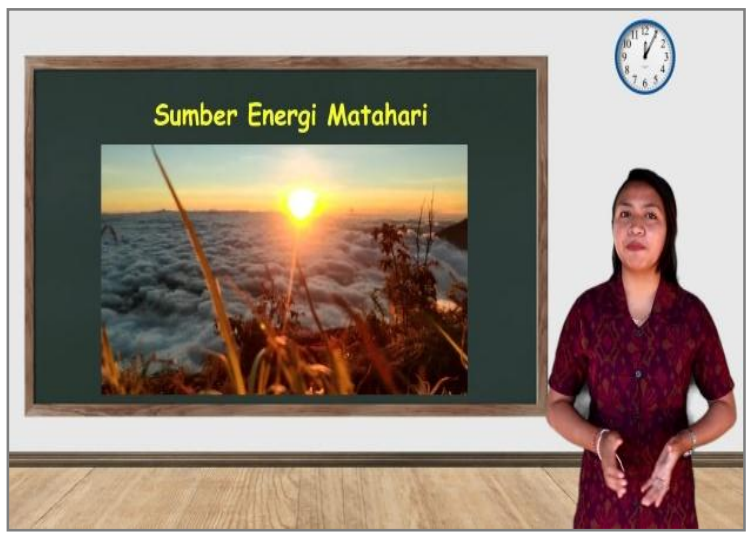

Gambar 2. Tampilan Materi dalam Media Video Pembelajaran

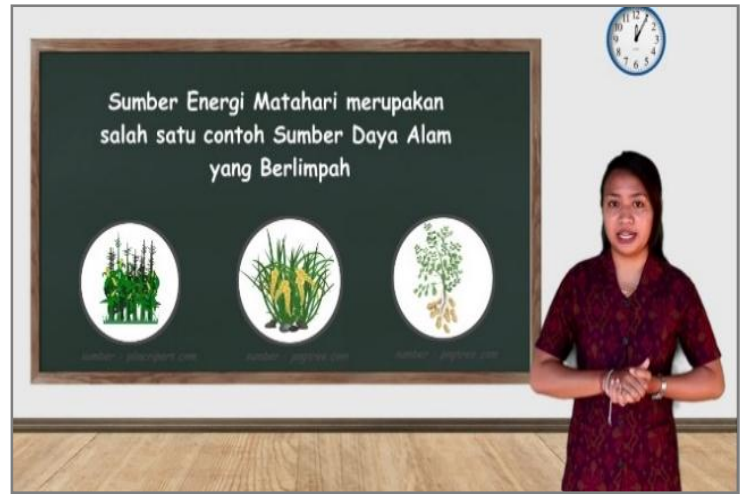

Gambar 3. Tampilan Contoh Ilustrasi pada Media Video Pembelajaran
Berdasarkan hasil penelitian pengembangan media video pembelajaran ini layak untuk diterapkan di SD N 4 Kampung Baru dengan memilih siswa kelas IV B yang total berjumlah 12 orang siswa sebagai subjek. Hal tersebut dapat dilihat dari beberapa aspek. Aspek pertama dilihat dari isi pembelajaran media video pembelajaran mendapatkan nilai sebesar $88 \%$ dengan kualifikasi baik. Berdasarkan hasil review tersebut dapat ditarik pemahaman bahwa media video pembelajaran yang dikembangkan sudah layak digunakan namun ada beberapa revisi dilakukan guna meningkatkan kualitas produk sehingga dapat mendukung proses pembelajaran ilmu pengetahuan alam. Hal tersebut didukung dengan materi yang disampaikan sudah sesuai dengan tujuan pembelajaran, ketepatan konsep penyampaian materi, ketepatan materi, kedalaman materi, kemenarikan materi dan kejelasan contoh-contoh yang diberikan sehingga dapat memotivasi siswa untuk belajar. Hal tersebut sejalan dengan yang disampaikan (Emda, 2017) bahwa motivasi belajar merupakan dorongan yang dapat menimbulkan perilaku tertentu yang terarah kepada tercapainya suatu tujuan tertentu. Selain itu materi yang dibahas secara rinci yang disertai dengan contoh memudahkan siswa dalam memahai materi yang disampaikan. Ilustrasi yang digunakan beragam mulai dari gambar, animasi, dan gambar nyata/rill sehingga dapat memotivasi siswa untuk belajar. Membicarakan materi yang bersifat nyata atau rill Sukiyasa \& Sukoco (2013) berpendapat bahwa materi yang disajikan secara jelas baik itu dari segi suara atau konten dan lebih nyata akan memudahkan siswa untuk memahami dan mengerti materi yang disajikan sehingga dapat berdampak kepada hasil belajar siswa.

Kunandar dalam (Imansari \& Sunaryantiningsih, 2017) menyatakan bahwa hasil belajar merupakan kompetensi yang dikuasasi setelah siswa mengikuti proses pembelajaran. Dari pendapat diatas 
dapat di petik pemahaman bahwa hasil belajar merupakan komponen penting dalam suatu proses pembelajaran disekolah. Hasil belajar digunakan sebagai tolak ukur bagi siswa dalam muatan pelajaran dimana semakin tinggi nilai siswa tersebut itu berarti semakin tinggi kemampuan dan pemahaman siswa terhadap muatan pelajaran tersebut. Hal tersebut sejalan dengan dengan hasil penelitian yang dilakukan oleh Suryansah \& Suwarjo (2016) bahwa produk media video pembelajaran yang dikembangkan cukup efektif untuk meningkatkan motivasi dan hasil belajar siswa, hal tersebut dibuktikan dengan hasil evaluasi yang telah dilakukan.

Selanjutnya dilihat dari aspek desain pembelajaran, media video pembelajaran memperoleh nilai 92\% dengan kualifikasi sangat baik. Hal ini dikarenakan dalam media video pembelajaran dilengkapi dengan petunjuk pengunaan media sihingga meminumalisir kesalahan dalam pengunaan media, ketepatan setrategi dan kesesuaian metode pembelajaran yang melandasi pengembangan video juga berpengaruh terhadap hasil video pembelajaran yang baik. Media video pembelajaran yang dikembangkan telah menerapkan segi desain pembelajaran didalamnya, ciri desain yang baik yaitu dapat menarik perhatian siswa, pesan mudah dipahami dan mudah dimengeri, informasi pesan yang disampaikan lengkap baik dari segi visual sehingga dapat mengangkat inti sari dari pesan yang akan disampaikan (Wahyudi, 2019). Hal ini dikarenakan media video yang dikembangkan, pemetaan materi cukup baik dan tampilan media video cukup menarik sehingga dapat meningkatkan motivasi maupun hasil belajar siswa, hal tersebut sejalan dengan hasil penelitian yang dilakukan oleh Agustini \& Ngarti (2020) bahwa dengan adanya media video yang dikembangkan lebih efektif dalam meningkatkan minat siswa untuk belajar pada mata pelajaran.

Selain itu ketepatan setrategi pembelajaran yang digunakan memudahkan siswa dalam memahami materi pelajaran. Media video pembelajaran yang dikembangkan berbasis audio visual dapat dipadukan dengan berbagai setrategi pembelajaran guna mendorong motivasi maupun minat belajar siswa. Hal tersebut juga sejalan dengan hasil penelitian yang dilakukan oleh Parlindungan et al., (2020) bahwa pemberian materi dengan media berbasis video efektif dalam proses pembelajaran, melihat respon yang merasa terbantunya dengan video pembelajran untuk pemahaan materi anak. Dari hasil penelitian diatas dapat ditarik pemahaman bahwa pengunaan media video pembelajaran cocok diaplikasikan pada strategi pembelajaran jarak jauh seperti saat ini, karena pengunaan strategi pembelajaran dan model pembelajaran yang tepat akan menarik minat dan mendorong motivasi belajar siswa karena kedua hal tersebut berdampak terhadap hasil belajar.

Selanjutnya dilihat dari aspek media pembelajaran, media video pembelajaran ini memperoleh nilai $85 \%$ dengan kualifikasi baik. Hal tersebut didukung dengan adanya penerapan desain pesan dalam media video pembelajaran ditunjukkan dengan kejelasan konten materi, pengunaan warna warna yang konsisten akan meminimalisir kesalahan pahaman dalam penyampaian materi, hal tersebut sesuai dengan pendapat Sudarma et al., (2015) bahwa warna merupakan unsur desain komunikasi visual dengan elemen grafis yang paling kuat serta provokatif dikarenakan warna dapat berbicara sebagai warna, warna sebagai representasi alam, dan warna sebagai ekspresi.

Kejelasan dan kemenarikan produk video pembelajaran akan meningkatkan minat maupun motivasi belajar siswa. penggunaan media video pembelajaran ini pun sangat sederhana dimana siswa hanya menonton video pembelajaran yang sudah disimpan di drive sehingga bisa diakses secara langsung maupun di downoad oleh siswa dan guru. 
Kemenarikan media video pembelajaran yang dikembangkan tidak terlepas dari setiap komponen yang ada dilamnya baik itu teks, gambar-gambar, animasi, video nyata dan suara didalamnya yang dibungkus menjadi satu, hal tersebut sesuai dengan pendapat Purwanto \& Rizki (2015) bahwa video pembelajaran adalah media pembelajaran yang berisi suara, gambar, gerak dan teks dan dikemas dengan singkat, padat dan jelas, hal tersebut menunjukan dalam media video pembelajaran juga dibutuhkan suara yang baik,berisi gambar atau ilustrasi dan teks yang nantinya dikemas dengan baik dan singkat.

Pengunaan media video pembelajaran merupakan salah satu komponen yang kompleks karena didalamnya mengandung unsur audio visual. Video sangat efektif digunakan apabila ingin menyampaikan informasi yang membutuhkan ruang dan waktu khusus seperti menampilkan perstiwa dimasa lampau, menampilkan hewanhewan buas, ruang angkasa dan lain sebagainya. (Berk, 2009) dalam penelitiannya menjelaskan bahwa belajar menggunakan media bergambar (video dan audio visual) lebih baik dari pada belajar dalam kondisi verbal. Hasil penelitian Moore \& Smith (2012) membuktikan bahwa peran media video sangat signifikan untuk meningkatkan minat keterlibatan siswa dalam pembelajaran. Hasil penelitian (Yunita \& Wijayanti, 2017) menunjukkan terdapat pengaruh penggunaan media video pembelajaran terhadap hasil belajar IPA siswa ditinjau dari keaktifan siswa. Video sebagai media yang digunakan pada pembelajaran dapat memperkaya pengalaman dan kompetensi siswa (Salim \& Tiawa, 2014). Dengan memanfaatkan video sebagai media pembelajaran, peserta didik mampu memahami lebih jelas tentang materi yang disampaikan oleh pendidik, tak hanya itu siswa juga dapat melihat dan merasakan secara langsung hal-hal yang sulit untuk dijangkau atau dilihat secara langsung. Untuk memahami suatu objek, tidak perlu menghadirkan objek nyata namun dapat digantikan dengan suatu bentuk yang dapat mewakili peran tersebut (Kurniawati et al., 2013). Adapun menurut Busyaeri et al., (2016) bahwa pemanfaatan video sebagai media pembelajaran pada bidang kognitif adalah mampu mengobservasi melewati ruang dan waktu seperti masa lalu, hal tersebut diperngaruh oleh unsur warna, suara, dan gerak yang mampu membuat karakter lebih hidup. Beberapa hasil penelitian menyatakan bahwa video sebagai media pembelajaran memiliki kontribusi yang positif terhadap hasil belajar siswa (Sarnoko et al., 2016; Irfan, 2016; Anzelina \& Purba, 2019). Oleh sebab itu pengunaan video sebagai pembelajaran tepat untuk digunakan pada muatan pelajaran ilmu pengetahuan alam karena siswa-siswa membutuhkan media yang mampu menampilkan ilustrasi agar siswa dapat mudah memahami materi yang disampaikan.

\section{PENUTUP}

Berdasarkan pada pemaparan diatas, dapat disimpulkan bahwa penelitian pengembangan media video pembelajaran dengan model ADDIE melalui lima tahapan pengembangan yaitu 1) analisis kebutuhan, 2) desain 3) pengembangan , 4) implementasi, dan 5) evaluasi. Melalui tahapan-tahapan pengembangan tersebut media video pembelajaran mata pelajaran IPA mencapai kualifikasi sangat baik. Berdasarkan hasil yang sudah diperoleh, media video pembelajaran yang dikembangkan layak digunakan sebagai sumber belajar untuk menarik minat belajar dan meningkatkan motivasi siswa sehingga dapat meningkatkan hasil belajar siswa.

\section{DAFTAR PUSTAKA}

Agustini, K., \& Ngarti, J. G. (2020). Pengembangan Video Pembelajaran untuk Meningkatkan Motivasi Belajar Siswa Mengunakan Model R\&D. Jurnal Ilmiah Pendidikan Dan Pembelajaran, 4(1),
62-78. 
https://doi.org/10.23887/jipp.v4i1.18403

Akbar, S., A'yun, I. Q., Satriani, F. Y., Widodo, W., Paranimmita, R., \& Ferisa, D. (2016). Implementasi Pembelajaran Tematik di Sekolah Dasar. Remaja Rosdakarya.

Anzelina, D., \& Purba, S. V. H. (2019). Pengaruh Penggunaan Media Pembelajaran Video Terhadap Hasil Belajar Siswa Pada Tema Kayanya Negeriku Di Kelas IV SD Swasta St. Antonius V Medan. Prosiding Seminar Nasional I Fakultas IImu Sosial Universitas Negeri Medan, 3, 752-761. http://digilib.unimed.ac.id/39414/1/18.Dewi.pdf

Arsyad, A. (2003). Media Pembelajaran. Raja Grafindo Persada.

Bavaharji, M., Alavi, Z. K., \& Letchumanan, K. (2014). Captioned Instructional Video: Effects on Content Comprehension, Vocabulary Acquition and Language Proficiency. Canadian Center of Science and Education, 7(5), 1-16. https://doi.org/10.5539/elt.v7n5pl

Berk, R. A. (2009). Multimedia teaching with video clips: TV, movies, YouTube, and $\mathrm{mtvU}$ in the college classroom. International Journal of Technology in Teaching and Learning, 5(1), 1-21.

Busyaeri, A., Udin, T., \& Zaenuddin, A. (2016). Pengaruh Penggunaan Video Pembelajaran Terhadap Peningkatan Hasil Belajar Mapel Ipa di Min Kroya Cirebon. Jurnal Pendidikan Guru MI, 3(1), 116-137. https://doi.org/10.24235/al.ibtida.snj.v3i 1.584

CNN Indonesia. (2020). Kemendikbud Buat Skenario Belajar di Rumah Sampai Akhir 2020. https;//www.cnnindonesia.com/nasional /20200424114337-20496861/kemendikbud-buat-skenariobelajar-di-rumah-sampai-akhir-2020

Emda, A. (2017). Kedudukan Motivasi Belajar Siswa dalam Pembelajaran. Lantanida Journal, 5(2), 172-182. https://doi.org/10.22373/lj.v
Imansari, N., \& Sunaryantiningsih, I. (2017). Pengaruh Pengunaan E-Modul Interaktif terhadap Hasil Belajar Mahasiswa pada Materi Kesehatan dan Keselamatan Kerja. Jurnal IImiah Pendidikan Teknik Elektro, 2(1), 11-16. https://doi.org/10.30870/volt.v2i1.1478

Irfan, A. (2016). Perbedaan Media Audio Visual dan bukan Audio Visual terhadap Motivasi dan Hasil Belajar IPS Siswa Kelas IV. Wahana Sekolah Dasar (Kajian Teori Dan Praktik Pendidikan, 24(1), 1-8.

Kemendikbud. (2020). Pelaksanaan Kebijakan Pendidikan dalam Masa Darurat Penyebaran Covid-19.

Kurniawati, A., Isnaeni, W., \& N.R. Dewi. (2013). Implementasi Metode Penugasan Analisis Video pada Materi Perkembangan Kognitif, Sosial, dan Moral. Jurnal Pendidikan IPA Indonesia, 2(2), 149-155. https://journal.unnes.ac.id/nju/index.ph p/jpii

Lestari, I. (2015). Pengaruh Waktu Belajar Dan Minat Belajar Terhadap Hasil Belajar Matematika. Jurnal Formatif, 3(2), 115-125. https://journal.Ippmunindra.ac.id/index. php/Formatif/article/viewFile / 118/115.

Moore, W. A., \& Smith, A. R. (2012). Effects of Video Podcasting on Psychomotor and Cognitive Performance, Attitudes, and Study Behavior of Student Physical Therapist. Innovations in Education and Teaching International, 49(4), 401-414. https://doi.org/10.1080/14703297.2012. 728876

Munir. (2009). Pembelajaran Jarak Jauh Berbasis Teknologi Informasi dan Komunikasi. Alfabeta.

Parlindungan, D. P., Mahardika, G. P., \& Yulinar, D. (2020). Efektifitas Media Pembelajaran Berbasis Video Pembelajaran dalam Pembelajaran Jarak Jauh (PJJ) di SD Islam AnNuriyah. Prosiding Seminar Nasional Penelitian LPPM UMJ, 1(1), 1-8. 
Jurnal.umj.ac.id/indeks.php/semnaslit

Purwanto, Y., \& Rizki, S. (2015). Pengembangan Bahan Ajar Berbasis Kontekstual Pada Materi Himpunan Berbantu Video Pembelajaran. Jurnal Aksioma, 4(1), 67-77. https://doi.org/10.24127/ajpm.v4i1.95

Putri, N. M. L. K., Parmiti, D. P., \& Sudarma, K. (2019). Pengembangan Video Pembelajaran dengan Bahasa Isyarat berbasis Pendidikan Karakter pada Siswa Kelas V di SDLB-B Negeri I Buleleng Tahun Pelajaran 2017/2018. Jurnal EDUTECH, 7(2), 81-91. https://doi.org/10.23887/jeu.v7i2.23162

Salim, K., \& Tiawa, D. H. (2014). Development of Media Based Learning Animation for Matematics Courses in Electrical Engineering. Internatonal Journal of Advanced Reasearch in Computer and Comunication Engineering, 3(10), 8332-8336. https://doi.org/10.17148/lJARCCE.201 4.31056

Sarnoko, Ruminiati, \& Setyosari, P. (2016). Penerapan Pendekatan Savi Berbantuan Video Pembelajaran Untuk Meningkatkan Aktivitas dan Hasil Belajar IPS Siswa Kelas IV SD N I Sanan Girimarto Wonogiri. Jurnal Pendidika: Teori Dan Pengembangan, 1(7), 1235-1241. https://doi.org/10.17977/jp.v1i7.6524

Sudarma, I. K., Tegeh, I. M., \& Prabawa, D. G. A. P. (2015). Desain Pesan Kajian Analisis Desain Visual Text dan Image. Graha IImu.

Sudatha, Wawan, I. G., \& Tegeh, I. M. (2015). Desain Muktimedia Pembelajaran. Media Akademi.

Sukiyasa, K., \& Sukoco. (2013). Pengaruh Media Animasi Terhadap Hasil Belajar dan Memotivasi Belajar Siswa Materi Sistem Kelistrikan Otomotif. Jurnal Pendidikan Vokasi, 3(1), 126-137. https://doi.org/10.21831/jpv.v3i1.1588

Sungkono. (2012). Pengengbangan Instrumen Evaluasi Media Modul Pembelajaran. Jurnal IImiah
Pembelajaran, 2, 1-16.

Suryansah, T., \& Suwarjo. (2016). Pengembangan Video Pembelajaran untuk Meningkatkan Motivasi dan Hasil Belajar Kongnitif Siswa Kelas IV SD. Jurnal Prima Edukasia, 4(2), 413-424. https://doi.org/10.21831/jpe.v4i2.8393

Tafonao, T. (2018). Peranan Media Pembelajaran dalam Meningkatkan Manfaat Minat Belajar Mahasiswa. Jurnal Komunikasi Pendidikan, 2(2), 103-114. https://doi.org/10.32585/jkp.v2i2.113

Tegeh, M., \& Jampel, N. (2017). Metode Penelitian Pengembangan. Universitas Penddikan Ganesha.

Wahyudi, N. G. (2019). Desain Pesan Pembelajaran Dalam Meningkatkan Mutu Pembelajaran di Era Digital. Jurnal Manjemen Pendidikan, 3(1), 104-135. https://doi.org/10.32478/evaluasi.v.3i1. 224

Yuanta, F. (2019). Pengembangan Media Video Pembelajaran IImu Pengetahuan Sosial pada Siswa Sekolah Dasar. Trapsila: Jurnal Pendidikan Dasar, 1(2), $\quad$ 91-100. https://doi.org/10.30742/tpd.v1i02.816

Yunita, D., \& Wijayanti, A. (2017). Pengaruh Media Video Pembelajaran Terhadap Hasil Belajar IPA Ditinjau dari Keaktifan Siswa. Jurnal LP3M, 3(2), 153-160. 